\title{
Tanggungjawab PPAT Dalam Pembuatan Akta Pembebanan Hak Tanggungan Dengan Jaminan Milik Anak Di Bawah Umur
}

\section{Dewi Tantini Wardaningsih}

Magister Kenotariatan Fakultas Hukum Universitas Islam Indonesia Yogyakarta Indonesia Jln. Cik Di Tiro No. 1 Yogyakarta Indonesia tantinidewi@gmail.com

Key Word: Abstract

APHT; guarantee; This study aims to determine the PPAT's responsibility in making the Mortgage Deed PPAT; minor (APHT) with the Underage Child Guarantor. The formulation of the problems proposed are: 1) How is the implementation of the agreement on the Deed of Mortgage Encumbrance (APHT) with minors, 2) What is the PPAT's responsibility in implementing the agreement on the Deed of Mortgage Encumbrance (APHT) with minors. This research includes a typology of juridical research. This research data was obtained from primary data through interviews with parties related to the problems to be studied. The results of this study conclude that there are procedures that are considered in the context of PPAT's responsibility in making a Mortgage Deed (APHT) with Underage Child Guarantor

\begin{tabular}{ll}
\hline Kata-kata Kunci: & Abstrak \\
\cline { 2 - 3 } APHT anak di & Studi ini bertujuan untuk mengetahui Tanggung Jawab PPAT dalam \\
bawah $\quad$ umur; & Pembuatan Akta Pembebanan Hak Tanggungan (APHT) dengan Penjamin \\
jaminan; PPAT & Anak di Bawah Umur. Rumusan masalah yang diajukan yaitu:1) Bagaimana \\
& pelaksanaan perjanjian Akta Pembebanan Hak Tanggungan (APHT) dengan \\
& anak di bawah umur, 2) Bagaimana tanggung jawab PPAT dalam pelaksanaan \\
& perjanjian Akta Pembebanan Hak Tanggungan (APHT) dengan anak di bawah \\
& umur. Penelitian ini termasuk tipologi penelitian yuridis. Data penelitian ini \\
& diperoleh dari data primer melalui wawancara kepada pihak yang terkait \\
& dengan permasalahan yang akan diteliti. Hasil studi ini menyimpulkan bahwa \\
& terdapat prosedur-prosedur yang diperhatikan dalam rangka tanggung jawab \\
& PPAT dalam Pembuatan Akta Pembebanan Hak Tanggungan (APHT) dengan \\
& Penjamin Anak di Bawah Umur. \\
\hline
\end{tabular}

\section{Pendahuluan}

Salah satu kegiatan usaha yang pokok bagi bank konvensional adalah berupa pemberian kredit dan dikenal dengan sebutan kredit perbankan. Pada proses pelaksanaan pemberian kredit perbankan tersebut biasanya dikaitkan dengan berbagai persyaratan, antara lain mengenai jumlah maksimal kredit, jangka waktu kredit, tujuan penggunaan kredit, suku bunga kredit, cara penarikan dana kredit, jadwal pelunasan kredit, dan jaminan kredit. ${ }^{1}$

Pasal 1 angka 11 Undang-Undang Nomor 10 Tahun 1998 tentang Perubahan atas Undang-Undang Nomor 7 Tahun 1992 tentang Perbankan (UU perbankan) menjelaskan bahwa kredit adalah penyediaan uang atau tagihan yang dapat dipersamakan dengan itu, berdasarkan persetujuan atau kesepakatan pinjam meminjam antara pihak bank

${ }^{1}$ M. Bahsan, Hukum Jaminan dan Jaminan Kredit Perbankan Indonesi, PT.Raja Grafindo Persada, Jakarta, 2015, hlm. 73. 
dengan pihak lain yang mewajibkan pihak peminjam untuk melunasi hutangnya setelah jangka waktu tertentu dengan jumlah bunga. Pendekatan ini dilakukan dengan cara menilai posisi neraca dan laporan rugi/laba untuk beberapa periode terakhir untuk mengetahui seberapa besarnya solvabilitas, likuiditas, dan rentabilitas usahanya serta tingkat risiko usahanya. ${ }^{2}$ Artinya nilai dan legalitas jaminan yang disediakan debitur cukup untuk menjamin fasilitas kredit dari bank, dan harus dikuasai atau diikat secara yuridis baik dengan mempergunakan akta otentik maupun akta di bawah tangan. Jaminan ini dimaksudkan untuk melunasi utang debitur apabila tidak bisa membayar atau mengembalikan kreditnya sesuai dengan waktu yang sudah diperjanjikansehingga memberikan kepastian hukum terhadap kreditur dan mempermudah debitur untuk melakukan kredit. ${ }^{3}$

Jaminan kebendaan ada yang yang bersifat bergerak dan tidak bergerak, jaminan tidak bergerak antara lain adalah tanah. Tanah merupakan jaminan yang paling diprioritaskan karena nilai ekonomis tanah yang tinggi dan tidak akan mengalami penurunan harga. Sehingga, sangat dimanfaatkan bagi kreditur untuk menjadi pengaman dalam peminjaman kredit bagi kreditur kepada debitur dengan pengikatan Hak Tanggungan oleh lembaga pengikatan jaminan Hak Tanggungan yang diatur dalam Undang-Undang Nomor 4 Tahun 1996 tentang Hak Tanggungan (UU HT). Hak Tanggungan merupakan perjanjian tambahan atau ikutan (accesoir) terhadap perjanjian pokok, dalam pelunasan hutang, kreditur merupakan kreditur preferen yaitu kreditur yang mempunyai hak pelunasan terlebih dahulu dari pada kreditur lain karena kreditur tersebut mempunyai jaminan yang diberikan oleh debitur. Pembebanan atau pemberian Hak Tanggungan diatur dalam Pasal 10 UU HT. Hak Tanggungan harus dibuktikan dengan sertifikat melalui pendaftaran Akta Pemberian Hak Tanggungan (APHT).

Dalam hal siapa yang berhak membebani Hak Tanggungan diatur dalam Pasal 8 ayat (1) UUHT yang menyebutkan, "pemberi Hak Tanggungan adalah orang perseorangan atau badan hukum yang mempunyai kewenangan untuk melakukan perbuatan hukum terhadap objek Hak Tanggungan yang bersangkutan. Dalam proses pemberian Hak Tanggungan, perlu juga pencantuman nama dan identitas pemegang dan pemberi Hak Tanggungan." Hal ini senada dengan Peraturan Pemerintah Republik Indonesia Nomor 24 Tahun 2016 Tentang Perubahan Atas Peraturan Pemerintah Nomor 37 Tahun 1998 tentang Peraturan Jabatan Pejabat Pembuat Akta Tanah yang mewajibkan PPAT untuk berhati-hati dalam pembuatan akta dan tanggungjawab PPAT dalam pembuatan akta tersebut.

Syarat kecakapan hukum harus terpenuhi dalam pelaksanaan APHT sebagaimana dalam salah satu syarat sahnya perjanjian. Pasal 1320 Kitab Undang-Undang Hukum Perdata (KUHPerdata) tentang Syarat Sahnya Perjanjian adalah adanya kata sepakat bagi mereka yang mengikatkan dirinya, kecakapan para pihak untuk membuat suatu perikatan, suatu hal tertentu, serta suatu sebab (causa) yang halal salah satunya mewajibkan para pihak cakap. Sedangkan dalam Pasal 1330 KUHPerdata menyebutkan

2 Ismail, Manajeman Perbankan: Dari Teori Menuju Aplikasi, Kencana, Yogyakarta, 2018, hlm. 48

3 Zaeni Asyhadie dan Rahma Kusumawati, Hukum Jaminan di Indonesia: Kajian Berdasarkan Hukum Nasional dan Prinsip Ekonomi Syariah, PT Rajagrafindo Persada, Depok, 2018, hlm. 40. 
bahwa salah satu subjek hukum yang dianggap belum cakap adalah orang-orang atau anak yang belum dewasa. Menurut Pasal 47 ayat (1) Undang-Undang Nomor 1 Tahun 1974 tentang Perkawinan yang selanjutnya disebut UU Perkawinan, "anak yang belum mencapai umur 18 tahun atau belum pernah melangsungkan perkawinan ada di bawah kekuasaan orang tuanya selama mereka tidak dicabut dari kekuasaannya".

Terdapat suatu praktik perbankan di salah satu bank di Yogyakarta di mana bank tersebut mencairkan kredit, dengan jaminan sertifikat tanah milik anak yang masih di bawah umur. Orang tua dari anak tersebut menjalankan kekuasaan atas anak yang masih di bawah umur. Sebab anak yang masih dibawah umur tidak bisa melakukan tindakan hukum sendiri. Seorang anak yang masih di bawah umur juga belum dianggap cakap menurut hukum untuk membuat surat kuasa dan sebagainya.

Pasal 48 UU Perkawinan menyebutkan bahwa orang tua tidak diperbolehkan memindahkan hak atau menggadaikan barang-barang tetap yang dimiliki anaknya yang belum berumur 18 tahun atau belum pernah melangsungkan perkawinan kecuali apabila kepentingan anak itu menghendakinya. Padahal pelaksanaan pembuatan APHT dengan jaminan sertifikat tanah milik anak di bawah umur harus mengingat kembali ketentuan hukum yang berlaku sebab anak di bawah umur dianggap belum cakap.

\section{Rumusan Masalah}

Berdasarkan latar belakang tersebut masalah yang dapat dirumuskan dalam penelitian ini yaitu pertama, bagaimana pelaksanaan perjanjian Akta Pembebanan Hak Tanggungan (APHT) dengan jaminan milik anak di bawah umur? Kedua, bagaimana tanggungjawab PPAT dalam pelaksanaan perjanjian Akta Pembebanan Hak Tanggungan (APHT) dengan jaminan milik anak di bawah umur?

\section{Tujuan Penelitian}

Penelitian ini bertujuan untuk: Pertama, mengetahui pelaksanaan perjanjian Akta Pembebanan Hak Tanggungan (APHT) dengan jaminan milik anak di bawah umur. Kedua, mengetahui tanggungjawab PPAT dalam pelaksanaan perjanjian Akta Pembebanan Hak Tanggungan (APHT) dengan jaminan milik anak di bawah umur.

\section{Metode Penelitian}

Penelitian ini merupakan penelitian yuridis yakni didasarkan pada penelitian kepustakaan tetapi untuk melengkapi data, dilakukan penelitian lapangan. Penelitian kepustakaan dimaksudkan untuk memperoleh data sekunder dan penelitian lapangan untuk memperoleh data primer. ${ }^{4}$ 


\section{Hasil Penelitian dan Pembahasan}

\section{Pelaksanaan Perjanjian Akta Pembebanan Hak Tanggungan (APHT) dengan Jaminan Milik Anak di Bawah Umur}

Sejak berlakunya UU HT, pembebanan hak jaminan atas tanah sebagai jaminan kredit dilakukan dengan pemberian Hak Tanggungan. Dengan demikian, hak jaminan dalam bentuk Hipotik dan Credietverband yang menggunakan peraturan lama, yaitu yang mengatur tentang Hipotik dan Credietverband, yang selama ini digunakan di dalam pembebanan Hak Tanggungan jaminan atas tanah sudah tidak berlaku lagi. ${ }^{5}$

Dalam memberikan Hak Tanggungan, pemberi Hak Tanggungan wajib hadir di hadapan PPAT. Pada saat pembuatan APHT, harus sudah ada keyakinan pada PPAT yang bersangkutan bahwa pemberi Hak Tanggungan mempunyai kewenangan untuk melakukan perbuatan hukum terhadap objek Hak Tanggungan yang dibebankan, walaupun kepastian mengenai dimilikinya kewenangan tersebut baru dipersyaratkan pada waktu pemberian Hak Tanggungan itu didaftar.

Pada tahap pemberian Hak Tanggungan oleh pemberi Hak Tanggungan kepada kreditor, Hak Tanggungan yang bersangkutan belum lahir. Hak Tangggungan baru lahir pada saat dibukukannya dalam buku tanah di Kantor Pertanahan. Oleh karena itu, kepastian mengenai saat didaftarnya Hak Tanggungan tersebut adalah sangat penting bagi kreditor.

Dapat dipahami bahwa, keberadaan APHT sangat penting terkait proses terbitnya sertifikat Hak Tanggungan. Sudah menjadi kewajiban bagi PPAT untuk menjamin keotentikan APHT yang dibuatnya, meneliti semua kelengkapan, dan keabsahan alat bukti atau dokumen yang diperlihatkan kepada PPAT, serta mendengar keterangan atau pernyataan para penghadap wajib dilakukan sebagai dasar pertimbangan untuk dituangkan di dalam akta.

Terkait dengan pelaksanaan perjanjian APHT dengan jaminan milik anak di bawah umur, Vincentius Harsono, selaku Kepala Bagian Regional CDCM (Credit and Document Collateral Management) and Trade Reprecentation Head Jawa Tengah di Bank X mengatakan bahwa tahapan-tahapan yang harus diperhatikan ialah sebagai berikut: 6

1. Pertama, harus terdapat suatu permohonan kredit atau pengajuan kredit dari pihak calon nasabah ke bank terlebih dahulu atau disebut aplikasi.

2. Alur proses pengajuan kredit sampai dengan putusan kredit.

3. Alur Proses Keputusan Kredit, Offering Letter dan Pencairan Kredit

4. Recieved Credit Approval (CA)/Menerima Keputusan Kredit.

Hal-hal yang dilakukan oleh analyst untuk memproses proposal permohonan kredit adalah melakukan: Analisis Rekening Koran; Analisis Laporan Keuangan; Analisis Karakter; Analisis kelayakan agunan; Analisis risiko; Kesimpulan dan rekomendasi.

Pada bagian akhir analisis memberikan kesimpulan atas hasil analisisnya dan memberikan rekomendasi atas proses kredit tersebut kepada pemutus kredit/komite kredit/approver, yang akan melakukan review atas proposal kredit untuk kemudian

5 Adrian Sutedi, Hukum Hak Tanggungan, Sinar Grafika, Jakarta, 2018, hlm. 115-116.

${ }^{6}$ Hasil wawancara dengan Vincentius Harsono, selaku Kepala Bagian Regional CDCM (Credit and Document Collateral Management) and Trade Reprecentation Head Jawa Tengah di PT. Bank X, 5 Agustus 2020. 
memberikan keputusan atas pengajuan kredit tersebut. Rekomendasi kredit menyimpulkan kredibilitas nasabah/calon debitur untuk menerima kredit maupun ketidak-layakan kredit dan usahanya tersebut, pada bagian ini harus dikemukakan alasan-alasan diterima maupun ditolaknya permohonan.

Dalam proses tersebut Bank $X$ juga memperhatikan prinsip 5C yang meliputi: Character atau watak debitur sangat menentukan kemauan untuk membayar kembali kredit yang telah diterimanya. Capacity mengandung arti kemampuan calon debitur dalam mengelola usahanya. Capital, yakni informasi mengenai besar kecilnya modal perusahaan calon debitur adalah sangat penting bagi bank. Collateral atau jaminan kredit merupakan setiap aktiva atau barang-barang yang diserahkan debitur sebagai jaminan atas kredit yang diperoleh dari bank. Conditions disini adalah keadaan perekonomian secara umum dimana perusahaan tersebut beroperasi.

Selain tahapan-tahapan tersebut di atas, perlu menjadi perhatian terkait pelaksanaan perjanjian APHT dengan penjamin anak di bawah umur ialah proses penerbitan Surat Penetapan Perwalian dari pengadilan. Menurut Suharso, selaku Ketua Panitera Muda Bagian Pidana, yang dahulu pernah menjabat sebagai Ketua Panitera Muda Bagian Perdata Pengadilan Negeri Bantul menyatakan bahwa Harus dipahami bahwa surat penetapan perwalian berdasarkan domisili di KTP pemohon jadi bukan berdasarkan letak tanah; ${ }^{7}$ kemudian pemohon dalam hal ini Nyonya $X$, memohon penetapan perwalian terhadap anak kandungnya yang saat itu masih berusia 16 tahun karena akan menjaminkan sebidang tanah pekarangan yang terletak di salah satu desa di Kabupaten Bantul atas nama anaknya tersebut di Bank X Cabang Yogyakarta untuk keperluan menambah modal usaha dan biaya pendidikan anak. Kemudian pemohon harus menyerahkan dokumen-dokumen yang dibutuhkan dan mengikuti alur permohonan. Setelah sidang permohonan selesai, pemohon menunggu selama 2-3 hari hingga putusan penetapan perwalian dapat diambil.

Berdasarkan hasil penelitian tersebut dapat diuraikan dalam suatu analisa dengan teori sebagai berikut:

Pasal 1320 Kitab Undang-Undang Hukum Perdata, tentang syarat sahnya perjanjian salah satunya mewajibkan para pihak cakap. Sedangkan dalam Pasal 1330 menyebutkan bahwa salah satu subjek hukum yang dianggap belum cakap adalah orang-orang atau anak yang belum dewasa.

Pengertian Perjanjian diatur dalam Buku II Buku III Kitab Undang-Undang Hukum Perdata tentang "Perikatan-Perikatan yang Dilahirkan dari Kontrak atau Perjanjian" dimana dalam dalam Pasal 1313 Kitab Undang-Undang Hukum Perdata merumuskan pengertian perjanjian yang berbunyi yakni suatu perjanjian adalah suatu perbuatan antara satu pihak atau lebih yang mengikatkan dirinya terhadap satu pihak atau lebih. Dalam hukum perjanjian ada beberapa asas, namun secara umum ada lima asas perjanjian, yaitu: ${ }^{8}$

${ }^{7}$ Hasil wawancara dengan Suharso, selaku Ketua Panitera Muda Bagian Pidana yang dahulu pernah menjabat sebagai Ketua Panitera Muda Bagian Perdata Pengadilan Negeri Bantul, pada 5 Agustus 2020.

${ }^{8}$ Mulyoto, Perjanjian Teknik Cara Membuat dan Hukum Perjanjian Yang Harus Dikuasai, Cakrawala Media, Yogyakarta, 2011, hlm. 36. 
a. Asas Kebebasan Berkontrak

Asas ini bermakna bahwa setiap orang bebas membuat perjanjian dengan siapapun, apapun isinya, apapun bentuknya, sejauh tidak melanggar undang-undang, ketertiban umum, dan kekusilaan (Pasal 1337 dan Pasal 1338 ayat (1) Kitab UndangUndang Hukum Perdata, yang mengatur bahwa, "Semua perjanjian yang dibuat secara sah berlaku sebagai undang-undang bagi mereka yang membuatnya."

b. Asas Konsensualisme

Asas konsensualisme dapat disimpulkan dalam Pasal 1320 ayat (1) Kitab UndangUndang Hukum Perdata. Dalam pasal itu ditentukan bahwa salah satu syarat sahnya perjanjian yaitu adanya kesepakatan kedua belah pihak. Asas konsensualisme merupakan asas yang menyatakan bahwa pernjanjian ada umumnya tidak diadakan secara formal, tetapi cukup dengan adanya kesepakatan kedua belah pihak.

c. Asas Pacta Sunt Servanda

Asas Pacta Sunt Servanda disebut juga dengan asas kepastian hukum. Asas ini berhubungan dengan akibat perjanjian. Asas ini merupakan asas bahwa hakim atas pihak ketiga harus menghormati substansi kontrak yang dibuat oleh para pihak, sebagaimana layaknya sebuah undang-undang mereka tidak boleh melakukan intervensi terhadap substansi kontak yang dibuat oleh para pihak selama tidak berlawanan dengan undang-undang, ketertiban umum, dan kesusilaan. Asas Pacta Sunt Servanda dapat disimpulkan dalam Pasal 1338 ayat (1) Kitab Undang-Undang Hukum Perdata yang mengatur, "Perjanjian yang dibuat secara sah berlaku sebagai undang-undang."

Berdasarkan Pasal 48 UU Perkawinan, orang tua tidak diperbolehkan memindahkan hak atau menggadaikan barang-barang tetap yang dimiliki anaknya yang belum berumur 18 tahun atau belum pernah melangsungkan perkawinan, kecuali apabila kepentingan anak itu menghendakinya.

Anak dari Nyonya X, selaku pemilik jaminan menurut hukum perdata di Indonesia dianggap tidak cakap hukum dan dilarang melakukan perbuatan hukum sehingga ia dilarang menjaminkan sertifikat tanahnya di bank karena belum cakap hukum. Nyonya $X$ selaku ibunya dan selaku debitur yang berhak mengelola harta si anak di bawah umur tersebut. Selanjutnya dapat dilihat bahwa dalam Undang-Undang Perkawinan, Nyonya $X$ tidak diperbolehkan menjadikan sertifikat si anak di bawah umur sebagai suatu jaminan hak tanggungan (kredit) di bank. Namun berdasarkan prakteknya telah dibuat APHT oleh PPAT dengan jaminan sertifikat tanah milik anak Nyonya $X$ yang masih di bawah umur. Hal tersebut dapat dijelaskan oleh bunyi redaksi selanjutnya dari Pasal 48 Undang-Undang Perkawinan Tahun 1974, bahwa karena Nyonya X memiliki alasan menjaminkan sertifikat untuk biaya pendidikan si anak dan menambah modal usaha Nyonya $X$ dalam rangka mencari nafkah bagi si anak tersebut, maka pembuatan APHT tidak bertentangan dengan peraturan perundang-undangan di Indonesia.

Praktek perbankan sendiri tidak hanya melihat dari alasan Nyonya X menjaminkan sertifikat tanah milik anak di bawah umur saja akan tetapi bahwa bank membutuhkan jaminan tertulis (lex scripta) berupa surat penetapan perwalian dari pengadilan bahwa Nyonya $\mathrm{X}$ selaku ibu kandung anak di bawah umur tersebut diangkat menjadi wali oleh pengadilan negeri kabupaten Bantul. Nyonya $X$ adalah ibu kandung si anak yang dapat dibuktikan dengan akta kelahiran si anak, tetapi harus meminta surat penetapan 
perwalian. Hal tersebut diwajibkan oleh bank supaya bank mendapat jaminan dari pengadilan bahwa benar Nyonya $X$ selaku debitur adalah seorang ibu yang memiliki anak kandung yang masih di bawah umur, dan dinyatakan mampu lahir dan batin menjadi wali bagi anak tersebut. Sehingga apabila terjadi masalah dalam proses pengikatan Hak tanggungan, maka pihak PPAT dapat meminta pertanggungjawaban pada Nyonya $X$ dengan adanya surat penetapan perwalian tersebut.

Adapun mengenai proses pemberian kredit langkah bank sudah benar untuk meminta jaminan dalam penelitian ini berupa sertifikat hak milik atas tanah anak Nyonya X. Hal tersebut dilakukan sebab bank selaku kreditur membutuhkan jaminan pelunasan kredit apabila Nyonya $X$ selaku nasabahnya melakukan wanprestasi sehingga pihak bank dapat didahulukan untuk mengambil pelunasan dari hasil penjualan tanah yang dijaminkan. Pembuatan APHT oleh PPAT dan pendaftarannya ke Kantor Pertanahan merupakan kepastian hukum bagi bank atas landasan hukum kepemilikan hak tanggungan sebab hak tanggungan lahir pada saat didaftarkan dalam buku pertanahan. Hal tersebut sekaligus memenuhi asas publisitas.

Artinya, pembuatan APHT dengan jaminan sertifikat tanah miliki anak di bawah umur di Bank X telah sesuai dengan peraturan perundang-undangan, maupun kebiasaan umum yakni dalam dunia perbankan. Adapun pembuatan APHT di kantor PPAT memenuhi kepentingan bank atas suatu jaminan pelunasan atas kredit yang diberikannya pada Nyonya X. Pendaftaran APHT oleh PPAT ke Kantor Pertanahan sudah memenuhi asas publisitas serta lahirnya hak tanggungan sebagai kepastian hukum bagi bank selaku pemegang hak tanggungan.

\section{Tanggungjawab PPAT dalam Pelaksanaan Perjanjian Akta Pembebanan Hak Tanggungan (APHT) dengan Jaminan Milik Anak di Bawah Umur}

Landasan filosofis diberinya kewenangan kepada PPAT untuk membuat akta-akta PPAT adalah memberikan kepastian hukum atas perbuatan hukum yang dilakukan para pihak, baik kepastian hukum tentang pemindahan hak atas tanah, APHT, SKMHT maupun pemindahan hak milik atas satuan rumah susun. Sebagaimana dalam Pasal 1 angka 1 Peraturan Kepala Badan Pertanahan Nasional Nomor 1 Tahun 2006 tentang Ketentuan Pelaksanaan Peraturan Pemerintah Nomor 37 Tahun 1998 tentang Peraturan Jabatan Pejabat Pembuat Akta Tanah (Perkaban Nomor 1 Tahun 2006), menyebutkan, "PPAT adalah pejabat umum yang diberi kewenangan untuk membuat akta-akta otentik mengenai perbuatan hukum tertentu mengenai hak atas tanah atau Hak Milik Atas Satuan Rumah Susun."

Salah satu tugas pokok PPAT yaitu menerbitkan APHT. APHT mengatur persyaratan dan ketentuan mengenai pemberian Hak Tanggungan dari debitur kepada kreditor sehubungan dengan utang yang dijaminkan dengan Hak Tanggungan. Edi Minarso, selaku ketua INI di Kabupaten Bantul ${ }^{9}$ mengatakan bahwa PPAT yang melaksanakan pembuatan APHT dengan Jaminan milik anak di bawah umur pembebanan Hak Tanggungan dilaksanakan melalui dua tahap yaitu tahap pemberian Hak Tanggungan dengan dibuatnya APHT oleh PPAT yang didahului dengan perjanjian hutang piutang dan tahap pendaftaran

${ }^{9}$ Hasil wawancara dengan Edi Munarso,Notaris dan PPAT Selaku Ketua INI Kabupaten Bantul pada 10 Oktober, 2020. 
dilakukan di kantor Pertanahan. Pembuatan APHT oleh PPAT sebagai dasar jaminan bagi kreditur yaitu dengan melakukan pembebanan Hak Tanggungan terhadap objek jaminan untuk melindungi kepentingan para pihak sebagai pemegang hak preferen. Dalam praktiknya, PPAT terlebih dahulu menerima berkas-berkas dari bank.

Kewenangan yang diberikan kepada PPAT untuk membuat akta-akta otentik mengenai perbuatan hukum tertentu mengenai hak atas tanah, termasuk dalam pembuatan APHT harus dilandasi dengan sikap profesional dan penuh rasa tanggungjawab oleh PPAT yang menjalankan tugas jabatannya. Tanggungjawab PPAT dapat timbul karena adanya kesalahan yang dilakukan PPAT pada saat menjalankan tugas jabatannya dan kesalahan itu menimbulkan kerugian bagi orang yang meminta jasa pelayanan kepada PPAT. Dengan bahasa yang sederhana dapat dikatakan bahwa setiap tugas atau kewajiban yang didasarkan atas kewenangan yang sah, baik yang bersumber dari undang-undang maupun dari perjanjian dapat menimbulkan tanggungjawab pada si pelaksana tugas atau kewajiban itu.

Setiap pemberian atau adanya suatu kewenangan senantiasa diikuti pula dengan kewajiban dan/atau tanggungjawab dari padanya. Oleh karena PPAT diberi kewenangan untuk membuat akta otentik, maka PPAT yang bersangkutan berkewajiban untuk memenuhi segala persyaratan yang telah ditentukan, khususnya dalam pembuatannya agar akta yang dibuat itu memenuhi syarat sebagai akta otentik yang sah. Kaitannya dengan pembuatan APHT oleh PPAT dengan jaminan milik anak di bawah umur maka PPAT yang bersangkutan wajib memastikan terpenuhinya segala syaratsyarat formil sesuai aturan-aturan yang telah ada, sebab jika syarat formil tidak terpenuhi maka dapat membuat APHT menjadi bersifat sebagai akta di bawah tangan.

Apabila akta otentik APHT dalam pembuatannya cacat hukum yang semata-mata disebabkan oleh kesalahan dari PPAT dan kemudian akta itu oleh pengadilan dinyatakan tidak otentik, atau tidak sah, atau menjadi batal demi hukum atau terdegradasi menjadi akta di bawah tangan, maka PPAT yang bersangkutan harus bertanggungjawab pada kliennya, bentuk tanggungjawab terhadap klien bisa berupa pemberian ganti rugi sepanjang klien yang bersangkutan terbukti menderita kerugian yang disebabkan adanya kesalahan yang telah dibuat oleh PPAT tersebut. ${ }^{10}$

Berdasarkan uraian tersebut, PPAT sudah memeriksa fakta penting dalam hal ini jaminan sertifikat tanah milik anak di bawah umur dalam pembuatan APHT. Berkas paling penting, meski semua berkas memiliki kedudukan penting, yang menyangkut isu anak di bawah umur menjaminkan sertifikat tanahnya, adalah terpenuhinya surat penetapan perwalian dari pengadilan bagi Nyonya $X$ selaku debitur.

PPAT harus memperhatikan terpenuhinyanya dokumen surat penerapan perwalian sebab isu yang dihadapi adalah anak di bawah umur yang menjaminkan sertifkat tanahnya di bank sebagai jaminan hak tanggungan. Apabila dokumen tersebut tidak terpenuhi maka PPAT dapat menyarankan untuk meminta surat penetapan perwalian di pengadilan. Artinya PPAT dalam penelitian ini sudah memenuhi asas kehati-hatian sebagai bentuk tanggungjawabnya, yakni memastikan adanya surat

${ }^{10}$ Habib Adjie, Aspek Pertanggungjawaban Notaris dalam Pembuatan Akta, Cetakan Kesat, CV. Mandar Maju, Bandung, 2011, hlm. 17-18. 
penetapan perwalian bagi PPAT untuk menjamin keotentikan APHT yang dibuatnya, meneliti semua kelengkapan, dan keabsahan alat bukti atau dokumen yang diperlihatkan kepada PPAT, serta mendengar keterangan atau pernyataan para penghadap wajib dilakukan sebagai dasar pertimbangan untuk dituangkan di dalam akta.

Adapun proses pendaftaran APHT ke Kantor Pertanahan sebagai pelaksanaan tugas PPAT untuk memastikan adanya asas publisitas hak tanggungan sebab pencatatan APHT di buku tanah Kantor Pertanahan merupakan saat lahirnya hak tanggungan.

\section{Penutup}

Bedasarkan analisis permasalahan di atas disimpulkan, pertama, pelaksanaan perjanjian APHT dengan Jaminan milik anak di bawah umur harus terpenuhi adanya Surat Penetapan Perwalian dari pengadilan. PPAT juga harus memberi penyuluhan hukum tentang semua kelengkapan dan keabsahan alat bukti atau dokumen yang dibutuhkan, dan mendengar pernyataan para penghadap wajib dilakukan sebagai dasar pertimbangan untuk dituangkan ke dalam akta. Pembuatan APHT sebagai jaminan bagi Bank harus diikuti pendaftaran di Kantor Pertanahan. Sebab saat tercatat di buku tanah adalah saat lahirnya hak tanggungan.

Kedua, bentuk tanggungjawab PPAT ialah dengan memenuhi kewajiban dalam hal kelengkapan dokumen yaitu dengan menjamin keautentikan APHT dan terpenuhinya surat penetapan perwalian dari pengadilan yang di dalamnya memuat ijin untuk menjaminkan tanah.

Saran dari peneliti adalah hendaknya para pihak untuk dapat mematuhi segala prosedur serta menjalankan tahapan yang telah diwajibakan dalam proses perjanjian APHT dengan penjamin anak di bawah umur agar dikemudian hari tidak terjadi kerugian-kerugian bagi para pihak yang terlibat di dalamnya. Dan dalam menjalankan tugas jabatan sebagai PPAT dan khususnya dalam hal pembuatan APHT, PPAT harus memperhatikan segala ketentuan-ketentuan yang sudah diatur dalam ketentuan Peraturan Perundang-undangan dan bekerja secara cermat serta tidak meninggalkan penerapan prinsip kehati-hatian, demi menghindari suatu perkara, dalam hal ini gugatan yang akan merugikan para pihak dan PPAT itu sendiri. PPAT harus sadar dan paham apabila ceroboh dalam bekerja maka akan menimbulkan suatu pertanggungjawaban bagi dirinya. Oleh sebab itu PPAT harus patuh dan taat dengan segala ketentuan-ketentuan dalam menjalankan tugas jabatan sebagai PPAT.

\section{Daftar Pustaka}

\section{Buku}

Adjie, Habib, Aspek Pertanggungjawaban Notaris dalam Pembuatan Akta, Mandar Maju, CV. Bandung, 2011.

Bahsan, M., Hukum Jaminan dan Jaminan Kredit Perbankan Indonesia, PT. Raja Grafindo Persada, Jakarta, 2015.

Ismail, Manajeman Perbankan: Dari Teori Menuju Aplikasi, Kencana, Yogyakarta, 2018.

Mulyoto. Perjanjian Teknik Cara Membuat dan Hukum Perjanjian Yang Harus Dikuasai, Cakrawala Media, Yogyakarta, 2011. 
Rahma Kusumawati, Zaeni Asyhadie. Hukum Jaminan di Indoensia: Kajian Berdasarkan Hukum Nasional dan Prinsip Ekonomi Syariah, PT Raja Grafindo Persada, Depok, 2018.

Soekanto, Soerjono. Pengantar Penelitian Hukum, Universitas Indonesia, Jakarta, 2018.

Sutedi, Adrian. Hukum Hak Tanggungan, Sinar Grafika, Jakarta, 2018.

\section{Peraturan Perundang-Undangan}

Kitab Undang-Undang Hukum Perdata

Undang-Undang Nomor 1 Tahun 1974 tentang Perkawinan

Undang-Undang Nomor 10 Tahun 1998 tentang Perubahan atas Undang-Undang Nomor 7 Tahun 1992 tentang Perbankan

Undang-Undang Nomor 4 Tahun 1996 tentang Hak Tanggungan atas Tanah Beserta Benda-Benda yang Berkaitan dengan Tanah

Peraturan Pemerintah Republik Indonesia Nomor 24 Tahun 2016 tentang Perubahan Atas Peraturan Pemerintah Nomor 37 Tahun 1998 Tentang Peraturan Jabatan Pejabat Pembuat Akta

Peraturan Kepala Badan Pertanahan Nasional Nomor 1 Tahun 2006 tentang Ketentuan Pelaksanaan Peraturan Pemerintah Nomor 37 Tahun 1998 tentang Peraturan Jabatan Pejabat Pembuat Akta Tanah

\section{Wawancara}

Wawancara dengan Vincentius Harsono, Kepala Bagian Regional CDCM (Credit and Document Collateral Management) and Trade Reprecentation Head PT. Bank X, di Jawa Tengah, 5 Agustus 2020.

Wawancara dengan Suharso, Ketua Panitera Muda Bagian Pidana yang pernah menjabat sebagai Ketua Panitera Muda Bagian Perdata Pengadilan Negeri Bantul, Yogyakarta, 5 Agustus 2020.

Wawancara dengan Nasabah Bank, pada 10 September 2020.

Wawancara dengan Edi Munarso Notaris dan PPAT Selaku Ketua INI Kabupaten Bantul pada 10 Oktober, 2020. 